\title{
Bartlomiej Michalak
}

\section{Naród czy rasa? Podobieństwa i różnice pomiędzy nacjonalizmem i narodowym socjalizmem}

Nacjonalizm jest jeđną $z$ tych ideologii, która wycisnęła swoje niepowtarzalne piętno $w$ historii świata. Sam nacjonalizm jest doktryną młoda. Jego początki przypadają na koniec XVIII w. i zmiany zapoczątkowane przez Wielką Rewolucją Francuską. Rozwój doktryny nacjonalistycznej wiąże się ściśle z kształtowaniem nowoczesnej świadomości narodowej wśród ówczesnych społeczeństw europejskich. Po Rewolucji mianem narodu przestano określać wąskie grono tak zwanych klas wyższych. Narodem stał się ogół wolnych obywateli urodzonych w danym

- kraju i posługujących się danym językiem ${ }^{1}$. $\mathrm{Z}$ nowym pojęciem narodu wiązać się musiały nowe zadania dla państwa, które straciło swój elitarny charakter, a stało się dobrem wspólnym. Państwo gwarantowało obywatelowi jego prawa i wolności, w zamian jednak żądało spełnienia pewnych powinności. By powinności te jawiły się obywatelowi jako ,naturalne”, potrzebna była jakaś idea integrujaca obywatela $z$ państwem. Państwo, stając się narodowym, zaczęło podkreślać, że działa "dla" i „w" imieniu narodu. Lojalność wobec współobywateli (którzy zmienili się w rodaków) stała się obowiązkiem moralnym. W ten sposób nacjonalizm stał się ideologia ,państwową", która „w tym ujęciu stała się ideologia podtrzymująca ów porządek, nową wizję człowieka i członka narodu"2.

W literaturze często podkreśla się zgubne wpływy myśli nacjonalistycznej na losy świata. Ma to szczególne znaczenie w obliczu takich

${ }^{1} \mathrm{~K}$. Tyszka, Wspólczesne dyskusje o nacjonalizmie, Społeczeństwo Otwarte, 1997 , nr 6, s. 12 .

${ }^{2}$ Ibidem. 
wydarzeń XX w., jak pojawienie się ideologii faszystowskiej czy jej niemieckiego wydania w postaci hitleryzmu. Genezę tych dwóch doktryn wywodzi się właśnie $z$ nacjonalizmu ${ }^{3}$. W tym teoretycznym ujęciu nazizm czy szerzej faszyzm stanowią po prostu skrajną emanację nacjonalizmu ${ }^{4}$, przy czym jego skrajność objawia się w niepohamowanej chęci zapewnienia praktycznej realizacji idei supremacji własnego narodu nad innymi. Supremacja ta miałaby być osiagnięta wszelkimi dostępnymi środkami włącznie $z$ biologiczną eksterminacją obcych etnicznie wspólnot.

Przyjęcie powyższych założeń nie ułatwia prób przybliżenia istoty obu doktryn. W tym bowiem ujęciu obydwie ideologie staja się prawie tym samym, a różnice między nimi sprowadzają się jedynie do środków i skali realizacji w gruncie rzeczy tych samych programów. Pogląd taki był propagowany szczególnie przez historiografię marksistowską. Wychodziła ona bowiem z założenia, że zarówno nacjonalizm, jak i faszyzm są w istocie wymysłem reakcyjnej burżuazji, która w ten sposób pragnęła skierować gniew rozgoryczonej ciężkimi warunkami bytowymi klasy robotniczej w inną stronę, aby w ten sposób odciagnąć ją od problemów społecznych i klasowych ${ }^{5}$. Wyjaśnienie takie może być tylko częściowo uzasadnione i raczej w odniesieniu do faszyzmu włoskiego niż nazizmu niemieckiego, gdzie zwłaszcza na początku swej działalności NSDAP (Nationalsozialistische Deutsche Arbeiterpartei - Narodowosocjalistyczna Niemiecka Partia Robotnicza) szeroko akcentowala w swym programie postulaty społeczne i antykapitalistyczne ${ }^{6}$.

Rozbieżności i spory wywołuje głównie brak sprecyzowania terminu „nacjonalizm", który w języku polskim nabrał złej konotacji i kojarzy się głównie $z$ szowinizmem, ksenofobią i bezgranicznym uwielbieniu własnego narodu. $Z$ kolei w literaturze anglosaskiej słowo to ma wyłącznie obiektywny i nie wartościujący odcień ${ }^{7}$. Generalnie rzecz ujmując, różnica w definiowaniu nacjonalizmu sprowadza się do tego, że dla Anglosasów pojęcie to obejmuje swym zakresem o wiele większe zjawisko niż

${ }^{3}$ Por. J. Justynski, Historia doktryn politycznych czasów nowożytnych, Tonú 1991 , s. 129.

${ }^{4}$ A. Czarnocki, Nacjonalizm, [w:] Encyklopedia politologii, [red.] M. Żmigrodzki, t. I, Teoria polityki, [red.] W. Sokół, M. Żmigrodzki, Kraków 1999, s. 196.

${ }^{5}$ J. Kuczyński, Indywidualnośc i ojczyzna, Warszawa 1972, s. 52.

${ }^{6}$ M. Maciejewski, Ruch i ideologia narodowych socjalistów $w$ Republice Weimarskiej. O źódlach i poczqtkach nazizmu 1919-1924, Warszawa-Wrocław 1985, s. 292.

${ }^{7}$ K. Tyszka, op. cit., s. 12. 
jego polski odpowiednik oraz ma czysto opisowe i neutralnie aksjologicznie znaczenie ${ }^{8}$. Na potrzeby tego eseju przyjęto anglosaskie kryteria ujmowania tego terminu oraz wykładnię zaproponowana przez Ernsta Gellnera, który definiuje nacjonalizm jako zasadę polityczną wedle której granice etniczne powinny pokrywać się z granicami politycznymi (państwowymi) .

Zmiany polityczne zapoczątkowane przez Oświecenie i Wielką Rewolucję Francuską $z$ jednej strony, oraz przemiany ekonomiczne zapoczątkowane przez rewolucję przemysłową $\mathrm{i}$ industrializację $\mathrm{z}$ drugiej strony, zniszczyły dotychczasowa strukturę społeczna. Jednostka miała stać się bardziej mobilna zarówno w wymiarze geograficznym, jak i zawodowym. Konieczność dostosowania się do nowych warunków wywoływać musiała ogromne frustracje związane $z$ porzuceniem swojego miejsca zamieszkania, stylu życia, itp. Rozbicie istniejących od wieków społeczności lokalnych, nierzadko znacznie tóżniących się od siebie, zmusilo państwo do wytworzenia homogenicznej kultury będącej warunkiem swobodnego komunikowania się ludzi, co miało ogromne znaczenie przy tworzeniu nowej gospodarki przemysłowej opartej na najemnej sile roboczej. Zbudowanie takiej jednorodnej kultury miało pomóc nie tylko w stworzeniu i rozwoju technicznie przygotowanej i wykształconej kadry wytwórczej, ale w zastapieniu dotychczasowej lokalnej, małej „ojczyzny” nowym, wspólnym dla wszystkich punktem odniesienia. Tym punktem miał być naród. Swoje wykształcenie i pozycje jednostki zawdzięczaly kulturze, w której się wychowały. Lojalność ziemi i religii zastapiona została przez lojalność wobec kultury. Tę kulturę symbolizować miała wspólnota narodowa ${ }^{10}$. Naród zdetronizowal nawet religię, gdyż ta nie gwarantowała już jedności politycznej. Stał się nowym absolutem, abstrakcyjnym i doskonałym. Stał się Bogiem ${ }^{11}$. Z tego przekonania o „boskości" narodu zrodziło się poczucie jego misji dziejowej i wyjątkowości. To właśnie wtedy, gdy mit narodowy ulega sakralizacji, staje się groźny i może przybrać nieobliczalne formy ${ }^{12}$. W tym momencie nacjonalizm „narodotwórezy" przeradza się $\mathrm{w}$ agresywny $\mathrm{i}$ zaborczy nacjonalizm

${ }^{8}$ K. Jaskułkowski, Nacjonalizm jako ideologia, Przegląd Politologiczny, 2003, nr 2, 2003, s. 37.

${ }^{9}$ E. Gellner, Narody i nacjonalizm, Warszawa 1991, s. 9.

${ }^{10}$ Ibidem, s. 49.

11 J. Kuczyński, op. cit., s. 51.

${ }^{12}$ F. Ryszka, Faszyzm, Przegląd Tygodniowy, 1997, nr 32, s. 16. 
„imperialistyczny", a ten może (choć nie musi) przerođzić się w faszyzm lub nazizm.

$\mathrm{Na}$ ogólne cechy doktryn nacjonalistycznych składają się zazwyczaj takie elementy, jak: (1) przekonanie o wyższości narodu nad jednostka, przy czym naród jest ujmowany jako wspólnota naturalna, (2) postulat odzyskania lub utrzymania niepodległości (tzw. nacjonalizm narodowowyzwoleńczy), (3) przekonanie, że świat podzielony jest na narody, a każdy $z$ nich ma swoją odrębną tożsamość ukształtowaną w procesie historycznym, (4) człowiek nie może istnieć bez wspólnoty narodowej, (5) jedynie państwo narodowe może zagwarantować narodowi pełen i nieskrępowany rozwój ${ }^{13}$. Czasami dochodzi do wyżej wymienionych kolejny element: (6) przeświadczenie o wyższości swojego narodu nad innymi. To właśnie $z$ tym ostatnim elementem często utożsamiany jest sam termin nacjonalizm. Tymczasem jest on składnikiem nowej mutacji tej doktryny. Przejściem od homogeniczności kulturowej do homogeniczności etnicznej. Dążenie takie pojawia się zwykle wtedy, gdy nowopowstała więź narodowa jest jeszcze słaba i potrzebuje silnego, emocjonalnie motywowanego poczucia wspólnoty. Nagromadzone napięcia społeczne moga doprowadzić do eksplozji, co stwarza zagrożenie rozpadu młodej struktury narodowej i podziału państwa. Najczęściej wtedy właśnie pojawia się postulat zastosowania kryterium „etniczności” w stosunkach między poszczególnymi członkami społeczeństwa. Ci wszyscy, którzy kryterium temu nie odpowiadaja, zostają napiętnowani, obwinieni o wszelkie niesprawiedliwości społeczne, o działalność ,,antynarodowa”, o przeszłe i bieżące problemy państwa, o złą sytuację materialną współobywateli, o blokowanie miejsc pracy, o spiski, szpiegostwo, zdradę, jednym słowem o całe zło świata, jakie miało lub ma miejsce w obecnej chwili. Taka grupowa dyskryminacja sprzyja integracji społecznej, pozwala na „przemieszczenie agresji" i przelanie jej na jakaśs wyodrębnioną grupe mniejszościową ${ }^{14}$. W ten sposób nacjonalizm wkracza w nową fazę rozwoju, odrzuca samą więź kulturową jako niewystarczającą na rzecz mglistej koncepcji „więzi etnicznej”. Od tej chwili nacjonalizm przestaje być doktryną „kulturotwórczą" i przechodzi na pozycje „zachowawcze”. Staje się „obrońcą prawdziwych interesów narodowych”, szermując hasłami

\footnotetext{
${ }^{13}$ K. Tyszka, op. cit., s. 14.
}

${ }^{14}$ Dokładnie koncepcje przemieszczonej agresji, a także rywalizacji ekonomicznej jako formy uprzedzeń opisuje Elliot Aronson w rozdziale swojej książki dotyczacym uprzedzeń. Zob. E. Aronson, Cztowiek istota spoleczna, Warszawa 1999 , s. $388-404$. 
szowinistycznymi, ksenofobicznymi, przeobraża się w agresywny i zaborczy nacjonalizm ,etniczny” i ,imperialistyczny".

Nacjonalizm niemiecki rozwijał się podobnie jak inne XIX-wieczne doktryny tego typu. Zrodził się jako skutek wojen wyzwoleńczych $\mathrm{z}$ lat 1813-1814. W połowie wieku jego najpilniejszą sprawą stało się zjednoczenie dotychczas podzielonych państw niemieckich w jedną polityczna i gospodarczą całość. Cel ten osiagnięty zostal dopiero w $1871 \mathrm{r}$., kiedy król Prus został cesarzem Niemiec ${ }^{15}$. Nowe teoretyczne koncepcje, które miały na celu uzasadnić niemiecki imperializm w kategoriach narodowych pojawiły się znacznie później, gdy Niemcy przystapiły do realizacji Weltpolitik. Ten tzw. ,klasyczny" nacjonalizm niemiecki reprezentowały zwłaszcza takie organizacje, jak: Związek Wszechniemiecki czy Liga Pangermańska. Organizacje te w swoich programach politycznych wzywały wszystkich Niemców do konsolidacji w obrębie wspólnego narodowego interesu. Tym interesem narodowym miała być nowa mocarstwowa pozycja Niemiec w świecie.

Dopiero jednak klęska Niemiec w I wojnie światowej i wynikające $z$ tej przegranej następstwa polityczne spowodowały gruntowne zmiany w niemieckiej doktrynie nacjonalistycznej. Przede wszystkim zaczęto wyraźnie akcentować problem ,ucisku" mniejszości niemieckiej w państwach Europy Środkowowschodniej. Układ polityczny, jaki powstał po wojnie, szczególnie sprzyjal powstawaniu w tej części Europy wielu konfliktów na tle etnicznym, co skwapliwie było wykorzystywane przez niemieckie organizacje i stowarzyszenia jawnie kwestionujące postanowienia Traktatu Wersalskiego. Utrata pozycji mocarstwowej szczególnie ubodła Niemców, którzy przestali identyfikować się z nowym, słabym, pokonanym i niejako "sztucznym" państwem. Więź narodowa, która w czasach cesarstwa skupiała się na terytorium Rzeszy i odnosiła do jej mieszkańców, teraz została przeniesiona na ponadpaństwowy naród $\left(\right.$ Volk) ${ }^{16}$. W ten sposób niemiecki nacjonalizm „państwowy” (mający na celu przekształcenie Niemców, mieszkańców landów w Niemców mieszkańców Rzeszy) przeistoczył się w agresywny nacjonalizm „etniczny” stawiający sobie za cel ekspansję na tereny, gdzie występowała jakakolwiek ludność związana z niemieckim obszarem kulturowym. Przy czym ekspansja ta miała być jedynie rekompensatą za krzywdy wyrządzone Niemcom po wojnie. Jeszcze w okresie II Rzeszy jeden $z$ głównych

${ }^{15}$ N. Davies, Europa. Rozprawa historyka z historiq, Kraków 1998, s. 876.

${ }^{16} \mathrm{R}$. Brubaker, Nacjonalizm inaczej. Struktura narodowa $i$ kwestie narodowe w nowej Europie, Warszawa 1998, s. 150. 
ideologów nacjonalizmu niemieckiego Heinrich von Treitschke pisał: „Najwłaściwszą rzeczą jest cywilizowanie barbarzyńskiego narodu. Trzeba mu dać do wyboru: albo będzie wchłonięty przez naród rządzący, albo zostanie wytępiony. [...] Chociaz taki proces rozwojowy jest okrutny, pozostaje on wszakże błogosławieństwem dla ludzkości. Nastapiło rozwiązanie słuszne - pierwiastek szlachetny pokonał i wchłoną mniej wartościowy"17. Ten punkt niemieckiego "programu narodowego" przejał nazizm z tạ jednak różnica, że termin „niemiecki obszar kulturowy” został zastapiony przez określenie „obszar poddany aryjskiemu wplywowi kulturotwórczemu".

Zarówno w okresie Republiki Weimarskiej jak i później w czasach III Rzeszy oficjalna propaganda podkreślała rzekome prześladowania Niemców za granicą. W ten sposób rozbudzony został nacjonalizm zrodzony z poczucia fizycznego zagrożenia. Opierał się on na przekonaniu, że przeciwnicy pierwsi zjednoczyli się i są gotowi do decydującego ataku. Dlatego też działania podjęte przez naród „zagrożony" sq̨ w istocie wtórne i obronne ${ }^{18}$.

Kolejnym zbieżnym składnikiem obu doktryn było przekonanie o wyjątkowej misji dziejowej narodu niemieckiego. Z tego też powodu Niemcom jako krzewicielom kultury należy się „przestrzeń życiowa” (Lebensraum). Wyraźnie pobrzmiewają tu echa imperialistycznej szkoły geopolitycznej Karla Haushofera i Friedricha Ratzela ${ }^{19}$. Trzecia Rzesza, w przeciwieństwie do Niemiec wilhelmińskich, nie domagała się ,swojego miejsca pod słońcem"20 (czyli należnej Niemcom pozycji mocarstwowej), ale pierwszego i jedynego miejsca na świecie.

Charakteryzując główne założenia teoretyczne narodowego socjalizmu należy pamiętać, że ideologia ta stanowiła zlepek złożony $z$ oderwanych, często bardzo różniących się od siebie elementów różnych doktryn filozoficznych i historycznych ${ }^{21}$. Przekonanie o zgubnym wpływie mie-

${ }^{17}$ Cyt. za: J. Pajewski, Historia powszechna 1871-1918, Warszawa 1998, s. 109.

${ }^{18}$ C. Taylor, Nacjonalizm i wspólczesność, Transit. Przeglad Europejski, 1996, z. 1 , s. 57 .

${ }^{19}$ K. Grünberg, SS-Gwardia Hitlera, Warszawa 1994, s. 90.

${ }^{20}$ Określenie użyte po raz pierwszy przez ówczesnego niemieckiego sekretarza stanu w Urzędzie Spraw Zagranicznych, a późniejszego kanclerza Bernharda Bulowa w oświadczeniu złożonym w 1897 r. Bülow powiedział wtedy między innymi: „Nikogo nie chcemy postawic w cieniu, ale domagamy się naszego miejsca pod stońcem"'. (Cyt. za: J. Pajewski, op. cit., s. 108.).

${ }^{21}$ F. Ryszka, Państwo stanu wyjątkowego, Wrocław 1985, s. 85. 
szania się ras nazizm zaczerpnął od Arthura Gobineau (1816-1882). Wiarę w misję dziejową Aryjczyków i szczególne predyspozycje Germanów od Houstona Stewarta Chamberlaina (1855-1927). Z filozofii nietzscheańskiej nazizm zaczerpnął nihilizm, oraz idee ,nadczłowieka" (Übermensch) i „narodu panów” (Herrenvolk). Postulowana przez hitleryzm „przestrzeń życiowa” (Lebensraum) była koncepcją Haushofera. Dobór koncepcji teoretycznych opierał się na kryterium zgodności z preferowaną przez NSDAP linią światopoglądowa. $\mathrm{Na}$ tej podstawie jeden z czołowych ideologów nazizmu Alfred Rosenberg jako niekwestionowanych prekursorów programu NSDAP jednym tchem wymieniał Chamberlaina, Wagnera i Nietzschego ${ }^{22}$.

W odróżnieniu od podkreślanych przez nacjonalizm związków z kulturą wyznaczających przynależność natodowa, nazizm traktował naród wyłącznie w kategoriach biologicznych powiązań. Mistyczne związki $\mathrm{z}$ krwią i ziemią (Blut und Booden) miały zastapić dotychczasowe filiacje $z$ kultura.

Jedna $\mathrm{z}$ fundamentalnych zasad głoszonych przez nową ideologię była nieprawdziwa teza stwierdzająca, że dzieje i rozwój świata sa zdeterminowane przez walkę „rasy wyższej” predysponowanej do rzadzenia cywilizacją $z$,rasą (rasami) słabsza”, skazanej na zagładę podobnie jak ma to miejsce $\mathrm{w}$ przyrodzie. "Nie ma innych rewolucji prócz rewolucji rasowych; nie może być rewolucji politycznej, ekonomicznej lub socjalnej, zawsze jest tylko walka niższej warstwy, gorszej rasy przeciwko panującej wyższej rasie i jeżeli ta wyższa rasa zapomni o swym prawie do życia, to poniesie klęskę"23.

Przeniesiono $\mathrm{w}$ zwulgaryzowanej formie prawo doboru naturalnego występujące w świecie zwierząt w sferę stosunków społecznych. Nieustanna walka stała się centralnym punktem programu Hitlera. Siła miała być pierwszym prawem. „Człowiek osiagnął wielkość dzięki walce. Wszystko do czego czlowiek doszedl, zawdzięcza swojej oryginalności plus brutalności... Całe życie związane jest $z$ trzema założeniami: walka jest źródłem wszystkiego, krew stanowi o cnocie, wodzostwo jest najważniejsze i decydujące" 24 .

Ta filozofia „walki” czerpała bezpośrednio z myśli Georga Wilhelma Friedricha Hegla. Byla to wizja $z$ jednej strony zbieżna $z$ nacjonalizmem

${ }^{22}$ M. Maciejewski, op. cit., s. 181.

${ }^{23}$ Wypowiedź Hitlera w czasie rozmowy z Otto Strasserem z roku 1930. Cyt. za: A. Bullock, Hitler - Studium tyranii, Warszawa 1997, s. 132.

${ }^{24}$ Mowa Hitlera w Chemnitz wygloszona 2 kwietnia 1938 r. Ibidem, s. 342. 
niemieckim (odwołanie się do koncepcji Hegla), z drugiej strony dotyczyła zupełnie innych podmiotów realizacji tej wizji. Hitler w odróżnieniu od Hegla uważał bowiem, że to nie walka narodów, ale ras jest siła sprawczą rozwoju dziejów. Koncepcja wspólnoty duchowej została zastapiona ideą wspólnoty biologicznej. Według Hitlera tylko Aryjczyk jako najbardziej wartościowy człowiek był budowniczym wszelkiej kultury występującej na ziemi. W „Mein Kampf" Hitler pisał między innymi: „Wszystko co dzisiaj podziwiamy na tej ziemi - nauka i sztuka, technika i wynalazki - jest tylko produktem małych narodów, a być może pierwotnie określonej rasy. Od nich zależy istnienie całej kultury. Gdy one zgina, zstapi z nimi całe piękno tej ziemi” ${ }^{25}$. W innym miejscu: „Gdyby podzielić ludzkość na trzy kategorie: twórców kultury, nosicieli kultury i niszczycieli kultury to jako przedstawiciel pierwszej w rachubę wchodziłby jedynie Aryjczyk $\$$.26.

Hitler uzależniał wszelki rozwój cywilizacyjny od zdolności „,kulturotwórczej" rasy aryjskiej. Tylko wtedy, gdy miała ona nieograniczone możliwości działania, mogła zagwarantować największy rozkwit ludzkiej kultury. Kultura była tworem określonej rasy i miała względem tej rasy wtómy charakter. Nie kultura więc (jak to było w nacjonalizmie), a rasa była fundamentem i spoiwem narodu w przekonaniu nazizmu. Z punktu widzenia pragmatycznego nacjonalisty rasizm jest pogladem głupim i niebezpiecznym zarazem, gdyż może przyczynić się do podważenia jedności narodu złożonego $\mathrm{z}$ wielorasowej wspólnoty historycznej ${ }^{27}$. Wedhug Franciszka Ryszki naród nie był nawet wyraźnie definiowany przez teoretyków nazizmu. Był raczej pewnym wyobrażeniem, bardziej typem idealnym niż zastaną rzeczywistością ${ }^{28}$. Hitler zresztą posługiwal się zamiennie pojęciami rasy i narodu. Rozróżnienie tych terminów nie miało dla niego najmniejszego znaczenia. Jedynie zagadnienie rasy było dla niego „,kluczem do historii świata”29. W rozdziale „Mein Kampf” poświęconym nacjonalizmowi Hitler umieszcza zaskakujące zdanie na temat narodu: „Po zniesieniu różnicy klas powstanie kiedyś naród złożony

${ }^{25}$ Cyt. za: J. Justyński, Wybór tekstów źródlowych z historii doktryn polityczno-prawnych, Toruń 1994, s. 275.

${ }^{26}$ Cyt. za: K. Grünberg, op. cit., s. 89.

27 J. Bartyzel, Fatalne nieporozumienie: nacjonalizm czy nacjonalitaryzm?, [w:] Historia $i$ polityka. Wiek XX. Studia z historii myśli politycznej $i$ idei, t. I, [red.] P. Tomaszewski, Toruń 2004.

${ }^{28}$ F. Ryszka, Faszyzm..., s. 16.

${ }^{29}$ M. Maciejewski, op. cit., s. 410 . 
z obywateli zjednoczonych i spojonych wspólną miłością i wspólną duma, niewzruszony i nigdy niezwyciężony" ${ }^{\text {"30 }}$.

Przemawiajac 7 maja 1933 r. w Kilonii do oddziałów SA Hitler stwierdził: „Musicie być gwarantami jej zwycięskiego [tj. rewolucji narodowosocjalistycznej - przyp. B. M.] zakończenia, a zakończy się zwycięsko, gdy w waszej szkole wykształci się nowy niemiecki naród"31. $\mathrm{Z}$ kolei w rozmowie Hermanem Rauschningiem wyraził się następująco: „Koncepcja narodu już nie ma znaczenia. Musimy odrzucić tę fałszywą koncepcję i zastąpić ją koncepcją rasy. Nowego porządku nie możemy sobie wyobrazić $w$ kategoriach granic narodu $z$ jego historyczną przeszłością, ale w kategoriach ras, co przekracza te granice.(...) Niewiele wówczas pozostanie $\mathrm{z}$ tego wyświechtanego frazesu, jakim jest narodowość, a spośród nas, Niemców, tylko cenna garstka. Zamiast tego zapanuje porozumienie między różnojęzycznymi elementami jednej wspaniałej rzadzacej rasy"32.

W założeniach wodza III Rzeszy taki „naród” miał więc dopiero powstać. Przy czym nie miała być to bynajmniej wspólnota równowartościowych obywateli. Spoleczeństwo miało być podzielone na trzy grupy: pierwszą mieli stanowić „pełnowartościowi bohaterzy" i na niej miał się opierać reżim. Grupę druga mieli tworzyć wszyscy „przeciętni”. Do ostatniej kategorii prędzej czy później skazanych na zagładę należeliby ci wszyscy, którzy z różnych względów nie spełnialiby oczekiwań reżimu. Nowy naród niemiecki miał być raczej kamą i zuniformizowaną struktura robotników - żołnierzy, niż bohaterów z sagi o Nibelungach ${ }^{33}$. Świadczyły o tym chociażby tzw. ustawy norymberskie, które nie przyznawaly obywatelstwa niemieckiego tylko i wyłącznie na podstawie cech rasowych, ale przede wszystkim na podstawie zgody reżimu ${ }^{34}$. To dowodzi o przedmiotowym traktowaniu wspólnoty narodowej przez reżim nazistowski. Przeczy więc podstawowej tezie nacjonalizmu głoszącej, że dobro narodu jest samo w sobie wartością najwyższą.

U Hitlera silny rasizm splatał się ze szczególnie agresywnym i napastliwym antysemityzmem. Te dwa elementy światopoglądu przywódcy

${ }^{30}$ Cyt. za: J. Justyński, Wybór tekstów.., s. 276.

${ }^{31}$ Cyt. za: A. Bullock, op. cit., s. 238.

${ }^{32}$ Ibidem, s. 343.

${ }^{33}$ F. Ryszka, U źródel sukcesu i klęski. Szkice z dziejów hitleryzmu, Warszawa 1972 , s. 62 .

${ }^{34}$ W. Kozub-Ciembroniewicz, Faszyzm w interpretacji Konstantego Grzybowskiego, Czasopismo Prawniczo-Historyczne, 1996, t. 48, z. 1/2, s. 197. 
NSDAP nawzajem wpływały i oddziaływały na siebie, tworząc charakterystyczny $\mathrm{i}$ obowiązkowy składnik doktryny narodowosocjalistycznej ${ }^{35}$.

Jednym z czolowych ideologów narodowosocjalistycznych był bałtycki Niemiec Alfred Rosenberg. W swojej zawiłej książce „Der Mythus des 20. Jahrunderts" (,Mit XX wieku"), szeroko propagował antysemityzm $\mathrm{i}$ antykomunizm. Wedhug Rosenberga wielkie państwa oraz liczące się ośrodki kultury uległy zagładzie w skutek nieprzestrzegania czystości rasowej. Jedynie prawdziwie germańskie pierwiastki zawarte $w$ rasie nordyckiej były zdolne do przezwyciężenia chaosu i zaprowadzenia porządku w świecie. Jednak by rasa nordycka mogła nad światem zapanować musiała bezwzględnie utrzymać „czystość krwi” nieskażonej domieszkami krwi ras niższych ${ }^{36}$.

Poglądy zbieżne $\mathrm{z}$ Rosenbergiem na temat roli rasy nordyckiej w dziejach świata reprezentował również Richard Walter Darré. Zapatrywania swoje przedstawił w książce pod tytułem „Bauerntum als Lebensquelle der nordischen Rasse" („,Chłopstwo jako źródło istnienia rasy nordyckiej”). Pseudonaukowe wywody Darré sprowadzały się do stwierdzenia, że jądrem rasy nordyckiej było chłopstwo $\mathrm{i}$ to ono uksztaltowało podstawy rozwoju cywilizacji i kultury. Szlachta germańska była w istocie tylko „uduchowionym chlopstwem”37. W oparciu o kulturę ludowa proponował Darré powrót do praktyk pogańskich. W ten sposób mial się odrodzić ,stary germański lud", który zerwałby z cała ,judeochrześcijańską" kultura, nawiazując tym samym do pradawnej świetności rasy nordyckiej. Była to więc koncepcja zmierzająca do realizacji idei Blut und Booden. Związek z kultura jako podstawą więzi narodowej miał być zastapiony nowym „misterium" - krwią rasy. Podkreślanie w doktrynie nazistowskiej roli chłopstwa jako pierwotnego ,składnika" narodu kłóci się $z$ lansowanym przez nacjonalizmy obrazem nowoczesnego, uprzemysłowionego i zintelektualizowanego narodu.

Rozpatrując założenia teoretyczne ideologii narodowosocjalistycznej trudno oprzeć się wrażeniu, że wiele jej założeń i postulatów jest ze sobą sprzecznych i niejasnych. Wydaje się to tym bardziej oczywiste, kiedy przeanalizujemy przemówienia kolejnych partyjnych dygnitarzy i przywódców NSDAP. Obliczone one były często na doraźny, tymczasowy efekt. Taktykę tą $\mathrm{z}$ powodzeniem wielokrotnie stosował sam Hitler.

\footnotetext{
${ }^{35}$ M. Maciejewski, op. cit., s. 410 .

${ }^{36}$ K. Grünberg, op. cit., s. 91.

${ }^{37}$ Ibidem, s. 97.
} 
W „Mein Kampf” pisał między innymi: „Każda idea może być źródłem niebezpieczeństwa, jeżeli się ją uważa za cel sam w sobie"38.

Ogólnikowe demagogiczne i populistyczne hasła propagandy nazistowskiej dostosowywały się do bieżącej sytuacji politycznej Niemiec. Bazowały w znacznej mierze na nie sprecyzowanych, płynnych tęsknotach podzielonego społeczeństwa ${ }^{39}$. Antykapitalizm mieszal się $z$ konserwatyzmem $i$ antykomunizmem. Raz podkreślano bardziej wątki antysemickie, innym razem nacjonalistyczne $i$ antybolszewickie. Ta charakterystyczna dla nazistowskiego reżimu cecha doprowadziła Alana Bullocka badajacego fenomen Hitlera w Niemczech do zasadniczego wniosku. Według Bullocka Hitlerowi chodziło o władzę dla siebie jako przywódcy narodu, z którym się identyfikował. Władza była jego najwyższym celem, a wszystkie poczynania były obliczone właśnie na zrealizowanie tego celu. Dlatego Hitler do końca obstawał przy pierwotnym programie partii z 1920 r., choć, jak sam twierdzil, był on już co najmniej od połowy lat dwudziestych nieaktualny. $W$ tym ujęciu ideologia miała charakter wtórny, a jej zadaniem było uzasadnianie poczynań władzy. Nie realizowała interesów narodu. Nie dobro narodu było jej celem, ale władza dla samej władzy ${ }^{40}$.

Mało oryginalny charakter tej ideologii nazistowskiej przejawiał się przede wszystkim w jej licznych zapożyczeniach z bogatej XIX-wiecznej myśli polityczno-filozoficznej ${ }^{41}$. Dlatego niezwykle trudno wskazać na pewne swoiste, charakterystyczne elementy tej doktryny. Dużo łatwiej jest wykazać to wszystko, przeciw czemu występowal nazizm. Tym łatwiej jest więc niemiecki faszyzm ujmować jako swoistą mutację nacjonalizmu w jego skrajnej postaci. Zdaniem Jerzego Krasuskiego narodowy socjalizm doprowadził niemiecki nacjonalizm do ostatecznej konsekwencji, ale tym samym spowodował jego zwyrodnienie ${ }^{42}$.

Bez wątpienia niemiecka myśl nacjonalistyczna w swym niezwykle agresywnym, „etnicznym" wydaniu była istotnym składnikiem ideologii narodowosocjalistycznej. Jej związek $z$ doktryną nazistowską polegał na kontynuowaniu pewnych jej założeń i wątków w warunkach kryzysu powojennego. Wykorzystywana była do podsycania nastrojów społecznego niezadowolenia ukierunkowanego antyrepublikańsko i rewizjoni-

\footnotetext{
${ }^{38}$ Cyt. za: A. Bullock, op. cit., s. 60.

${ }^{39}$ F. Ryszka, Państwo..., s. 88.

${ }^{40}$ A. Bullock, op. cit., s. 60.

${ }^{41}$ M. Maciejewski, op. cit., s. 178.

${ }^{42}$ Ibidem, s. 185.
} 
stycznie $^{43}$. Utożsamianie obydwu doktryn wynika często $\mathrm{z}$ faktu szerokiego poshugiwania się przez nazistów frazeologią narodową. Błąd polega na tym, że nazizm zupełnie inaczej pojmował naród i wspólnotę narodową. Podczas gdy w nacjonalizmie naród traktowano jako dziedzictwo wartości, tradycji, czyli wszystkiego tego, co się odnosi do sfery kulturowej i duchowej, narodowy socjalizm upatrywał w narodzie niemieckim egzemplifikacji wspólnoty rasowej. Nacjonalizm odwoływał się do wspólnej kultury, gdyż wlaśnie na bazie jednorodnej kultury powstaky narody. Czynnik etniczny był więc wtórny w stosunku do tej kultury. Najpierw musiała istnieć jedna homogeniczna kultura, aby na jej bazie wyksztalciły się wszystkie inne więzi. Twierdzenie, że o przynależności narodowej decyduje czynnik pochodzenia ma zastosowanie dopiero $w$ odniesieniu do kolejnych pokolen dziedziczących po swych kulturowo jednorodnych przodkach, ale do nich samych odnosić się nie może. Oni bowiem dopiero stworzyli tę nową wspólnotę ,przodków". Nacjonalizm nie wyklucza zresztą asymilacji obcych „etnicznie" zbiorowości. Taka asymilacja związana jest właśnie $\mathrm{z}$ akulturacja.

Inaczej sprawa ta była postrzegana przez teoretyków hitleryzmu. Nazizm kładł bowiem zdecydowany nacisk na wspólnotę krwi, którą pojmował jednak w kategoriach dziedziczności. Tutaj wspólna tożsamość kulturowa nie była wystarczającym warunkiem przynaleźności do narodu. Wręcz odwrotnie, doktryna hitlerowska starała się wykazać, że dotychczasowa niemiecka mentalność jest zła, bo jest przepełniona chrześcijańsko-judaistycznymi elementami. Charakter tej kultury miał być więc destruktywny. Należało przeto ją odrzucić jako zdegenerowana i zastapić ,prawdziwa" starogermańską tradycja. Narodowy socjalizm miał być ruchem ,rewolucyjnym". Zakładał przebudowanie całego dotychczasowego światopoglądu niemieckiego w duchu „aryjskim”. Mistyczne związki krwi z ziemią (Blut und Booden) miały zastapić dotychczasowe więzi z kultura. Dominującymi składnikami nazistowskiej koncepcji narodu, w przeciwieństwie do nacjonalizmu, były też antysemicko podbudowany rasizm i irracjonalny kult rasy nadczłowieka (Überme$n s c h$ ). Podczas gdy nacjonalizm nawiązuje do wspólnoty duchowej i moralnej poszczególnych członków narodu opartej na wspólnym dziedzictwie historycznym oraz zgodzie i woli życia w jednych granicach, nazizm

${ }^{43}$ Ibidem, s. 186. 
ujmuje tę więź wyłącznie $w$ ramach biologicznych ${ }^{44}$. W doktrynie nazistowskiej to Führer stal się głosem, sędzią i sumieniem narodu. Staną1 ponad narodem, stał się jego substytutem. „Führer jako najwyższy i jedyny ustawodawca miał wyrażać nie swą wolę, ale wolę narodu”, ${ }^{\text {"45 }}$. Rudolf Hess krzyczał na wiecu partyjnym "Niemcy to Hitler, Hitler to Niemcy". Tylko wódz wiedział co jest najlepsze dla Niemiec. Bezwzględne posłuszeństwo w myśl hasła ein Volk, ein Reich, ein Führer stało się pierwszym wyznacznikiem przynależności do "nowego narodu". Tak więc naród niemiecki miał być nie tylko wspólnotą krwi, ale i światopoglądu. Trawestując Konstantego Grzybowskiego, który stwierdzil, że ustrój polityczny III Rzeszy opierał się na „rasistowsko podbudowanym nacjonalizmie", można powiedzieć, że ideologia III Rzeszy opierała się na ,nacjonalistycznie podbudowanym rasizmie"46.

Nacjonalizm w swym pierwszym okresie istnienia określanym w niniejszej pracy jako tzw. nacjonalizm ,państwowy", spelniał pozytywną narodotwórczą rolę. Za pomocą aparatu państwowego ksztaltował nowa wspólną kulturę, która była koniecznym warunkiem przejścia od społeczeństwa agrarnego do industrialnego. Nie oznacza to bynajmniej, ze ewolucja taka jest zupełnie niemożliwa w innych warunkach. Jest jednak znacznie utrudniona, a tam, gdzie do integracji w ramach kultury nie dojdzie, rodzą się szybko społeczne i polityczne konflikty na tle grupowym. Nowoczesne państwo industrialne potrzebowało nowej, trwale zintegrowanej wspólnoty społecznej. Taką wspólnotę może stanowić naród. Analizując myśl nacjonalistyczną należy pamiętać jednak, że w tworzonych przez nią kulturach wszystko zostaje przekręcone: nacjonalizm ma bronić kultury ludowej, tradycji, dawnego „narodowego" porządku. Tymczasem jest zupełnie odwrotnie. To on właśnie stwarza tę nową kulturę, ustanawia tradycje, wymyśla mity, by je później gloryfikować, buduje społeczeństwo masowe $\mathrm{i}$ anonimowe ${ }^{47}$. Jest bałwochwalczy, kiedy głosi przewage narodu nad jednostką, motywując to swoistą "misją dziejową" narodu. Ma charakter zabobonny, gdy stwierdza, że naród jest „dany od Boga", a przynależność do niego koniecznym warunkiem rozwoju czło-

${ }^{44}$ Koncepcje narodu jako wspólnoty opartej na zasadzie duchowej zaczerpnąłem od Emesta Renana. Zob. J. Justyński, Historia doktryn ..., op. cit., s. 130; Slownik polityki, [red.] M. Bankowicz, Warszawa 1996, s. 161.

${ }^{45}$ F. Ryszka, Państwo..., s. 271.

${ }^{46}$ Zob. W. Kozub-Ciembroniewicz, op. cit., s. 196.

${ }^{47}$ E. Gellner, op. cit., s. 150-151. 
wieka $^{48}$. Przybierając formy coraz bardziej gloryfikujące wspólnotę narodową staje się niebezpieczny. W tym bowiem momencie pojawia się postulat „Zabezpieczenia” narodowej kultury przed wpływami „obcych”. Prowadzić to musi do nietolerancji i dyskryminacji. W rezultacie pojawiają się hasła ksenofobiczne, antysemickie, itd. Wreszcie, gdy brak już „widzialnych wrogów" pojawia się postulat „czystości rasowej”. Z chwila gdy czynnik etniczny zastapiony zostanie rasowym nacjonalizmem opartym na agresywnym antysemityzmie i szowinistycznym imperializmie, można już mówić o tworzeniu się nazizmu.

Nie musi jednak tak się staé. Nie każdy nacjonalizm prowadzi w konsekwencji do nazizmu czy faszyzmu. Nazizm charakteryzowal się przede wszystkim rasizmem, antysemityzmem, darwinizmem społecznym i koncepcja ,nieomylnego" wodza. W ujęciu nazizmu kultura była pochodna przynależności rasowej. To rasa stworzyła kulturę, a nie odwrotnie. Sama kultura nie ma większego znaczenia, gdyż nie jest warunkiem istnienia narodu czy rasy. Plemienno-rasowy nacjonalizm, a właściwie nacjonalitaryzm (określenie zaproponowane przez Jacka Bartyzela), który jest endemicznym składnikiem nazizmu postrzega bowiem naród jako rasę antropologiczną. Nacjonalizm zaś bardziej jako "rasę historyczną,499. Inaczej rzecz ujmując, nazizm definiuje naród przez pryzmat rasy, która stanowi obiektywny składnik zarówno biologicznej, jak i społecznej natury człowieka, przy czym tylko jego własna rasa powinna mieć zagwarantowane nieograniczone prawo rozwoju. Nacjonalizm buduje tożsamość narodową na fundamencie kulturowej homogeniczności. W tym ujęciu naród stanowi zbiorowość jak najbardziej realną, ale połączoną wspólnotą tradycji i historii z pokoleniami przeszłymi i przyszłymi. Koncentrując się na sobie nie neguje wszak praw innych kultur do istnienia $\mathbf{i}$ rozwoju. Jeżeli więc duchowa wspólnota jaką jest naród nie da się porwać irracjonalnym postulatom „etniczności”, a pozostanie wierna koncepcji współżycia w ramach nie tyle „narodu” co „kultury”, to doktryny odwołujące się do nierówności narodowych czy rasowych raz na zawsze stracą rację bytu.

${ }^{48}$ J. M. Bocheński, Nacjonalizm, [w:] Sto zabobonów. Krótki filozoficzny slownik zabobonów, Kraków 1992, s. 86.

${ }^{49}$ J. Bartyzel, op. cit., s. 19. 